\title{
SEASONAL DYNAMICS OF PARASITES ON MEDITERRANEAN MUSSELS (Mytilus galloprovincialis) AND ECOLOGICAL DETERMINANTS OF THE INFECTIONS IN SOUTHERN ALBORAN AREA, MOROCCO
}

\author{
BHABY S. ${ }^{1,2^{*}}$, BELHSEN O.K. ${ }^{2}$, ERRHIF A. ${ }^{1}$ AND TOJO N. ${ }^{3}$ \\ 1 University Hassan II, Casablanca, Laboratory of Aquatic ecology and Environment, Casablanca, Morocco. \\ 2National Institute of Halieutic Research, Laboratory of Shellfish Pathology, Casablanca, Morocco. \\ 3IMPM Project, National Institute of Fisheries Research, Casablanca, Morocco. \\ ${ }^{*}$ Corresponding Author: Email- s.bhaby@yahoo.fr
}

Received: October 11, 2013; Accepted: November 09, 2013

\begin{abstract}
This paper aim to provide information in the major parasitic pathogens found in Mediterranean mussel, Mytilus galloprovincialis from south Mediterranean population of the bay of M'diq, in Morocco. The parasitic prevalence in relation to the reproductive cycle and the environmental conditions were investigated, and potential determinants of the infection were discussed. Mussels were monthly collected from March 2009 to March 2011. To examine the reproductive stage of the M. galloprovincialis and pathological status, histological approach was taken for the analysis. Common parasites including regionally problematic Marteilia refringens were observed in the specimen. We found the Ciliophora-like Protozoan group in digestive diverticula (43.33\% of hosts). Steinhausia mytilovum is observed in oocytes of the host, and its prevalence was up to $32 \%$. The presence and absence of the Ciliophora-like group had a significant relationship with variation of salinity in the site $(p<0.05)$, and the presence and absence of the $S$. mytilovum had a significant relationship with change in the gonadic index $(p<0.05)$. The negative impact of parasites upon the local population of $M$. galloprovincialis at the site was not major during the surveyed years. No mortality due to the parasitic diseases has been observed in mussels in M'diq. However, the found relationships between the parasite and host and environmental condition suggest that the variability of the environment in the site would cause unanticipated outbreaks. Considering the importance of mussels for Moroccan mytilicultre in the southern Alboran, comprehensive monitoring of the pathological status and host and environmental condition is necessary.
\end{abstract}

Keywords- Mytilus galloprovincialis, parasites, Steinhausia mytilovum, Ciliophora, the Mediterranean Sea, histopathology

Citation: Bhaby S., et al. (2013) Seasonal Dynamics of Parasites on Mediterranean Mussels (Mytilus galloprovincialis) and Ecological Determinants of the Infections in Southern Alboran Area, Morocco. International Journal of Parasitology Research, ISSN: 0975-3702 \& E-ISSN: 09759182, Volume 5, Issue 1, pp.-116-121.

Copyright: Copyright@2013 Bhaby S., et al. This is an open-access article distributed under the terms of the Creative Commons Attribution License, which permits unrestricted use, distribution and reproduction in any medium, provided the original author and source are credited.

\section{Introduction}

The Mediterranean mussel (Mytilus galloprovincialis) is one of the shellfishes, distributing over littoral zone of Morocco from the Atlantic Ocean to Mediterranean Sea [1-3]. In Alboran, the intersecting area of Mediterranean Sea to the Atlantic Ocean from the strait Gibralter to Sebta marg, M. galloprovincialis essentially resides along rocky coast line $[4,5]$. Aggregations of the mussels were confirmed in the fossil record since more than 30 million years ago based on Lecointre [6]. History of human consumption can be found since 6000 B.C., and the mytiliculture for mussels is active in recent years $[7,8]$. The high primary production has made Alboran an important habitat of shellfish.

Recently, the demographic growth along the littoral zones pressured on natural population of the mussels including M. galloprovincialis. To enhance the sustainability of the mussel production, artificial breeding has been made, but it the efforts have not been successful overall. From 2005 to 2010, the production of M. galloprovincialis was variable between 0 to 34 tons per year in spite of the multiple breeding efforts. Fundamental understanding upon the local population of this mussel is still under investigation, and scien- tific explanations on the mortality and variability of the recruitment success is necessary.

The infection of parasites is the one of the dominant causes of the mass mortality of the natural and cultured stock of the shellfish [912]. For dense aggregation of mussels with byssal threads, including M. galloprovincials, outbreak of parasites may be mortal risk for whole community. Villalba, et al [13] reported the presence of Marteilia refringens, major pathogen of oyster (Ostrea edulis), has been associated with mortalities of $M$. galloprovincialis in Spain. Presences of microsporidia, the turbellarian Urastoma cyprinae, the copepode Mytilicola intestinalis and Steinhausia mytilovum were also observed in their investigations. The pathogenic resistance of mussels including $M$. galloprovincials has been discussed in relation to the environment, and the sensitivity of the mussels to the local thermal conditions with parasites was indicated [14]. As discussed, histo-pathological approach along the reproductive cycle in relation to the surrounding is probably practical to diagnose the pathological state of the local population of M. galloprovincials [15]. Oceanographic condition of $M$. galloprovincialis in Alboran is locally dynamics. The coastal area is especially known as a transitional 
zone of low-salinity inflow from the Atlantic Ocean and outflow of the Mediterranean Sea $[4,16]$. For the interpretation of local population responses of $M$. galloprovincialis, variability of the marine environmental conditions should be taken into account. Unfortunately, there are limited numbers of the ecological studies of shellfishes in Alboran especially in southern area. Though some efforts were made from physico-chemical and bacteriologic perspectives in the M'diq bay of Alboran [17], population-specific ecological investigations in environmental determinants of $M$. galloprovincialis in southern Alboran have been expected. Pathological studies with ecological interpretation would provide the key for the sustainable production of the socio-economically important mussel. However, there was no such a study in this area in the past.

This study aim to histopathologically evaluate the occurrence of endoparasitic species in $M$. galloprovincialis at M'diq, one of the major aquacultural area in Alboran, from March 2009 to March 2011. Then we investigated the relationship between major parasites and the environmental variables along the change in reproductive conditions of $M$. galloprovincialis. Discussion was made based on the results from the statistical analyses in dependencies of provenance upon both host's biological conditions and environmental variables. As a potential impact, heamocytic infiltration of the parasites upon reproduction of $M$. galloprovincials was also investigated.

\section{Materials and Methods}

\section{Study Site and Sampling}

The study site is located at the western Alboran, Mdiq, Morocco $\left(35^{\circ} 41^{\prime} \mathrm{N} ; 5^{\circ} 18^{\prime} \mathrm{W}\right)$ where the Atlantic inflow of the Strait of Gibraltar $[18,19]$, Mediterranean water, and coastal inflow [Fig-1]. Adults Mediterranean mussels were sampled from aquacultural cages at a depth of 3 meters $(>40 \mathrm{~mm})$ around aquacultural facility $\left(35^{\circ} 41^{\prime}\right.$, $28 \mathrm{~N} ; 5^{\circ} 18^{\prime}, 07 \mathrm{~W}$ ), from 500 meters offshore of Cabo Negro to 1.6 $\mathrm{km}$ of from M'diq port [Fig-1].

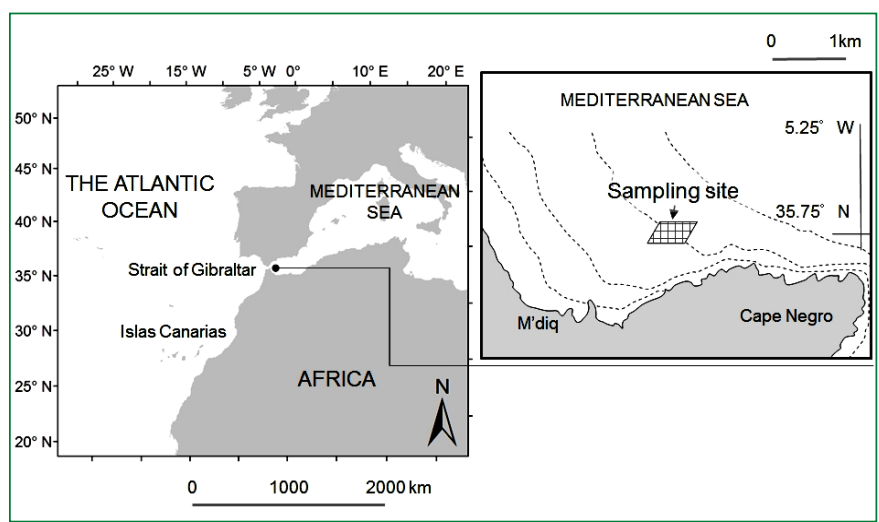

Fig. 1- Geographical study area of sampling site (M'diq), nearby Cape Negro (Koudiat Taifor); the sampling site was conductor in the depth range between 20 and 24 meters [24].

From March 2009 to March 2011, 30 specimens of M. galloprovincialis $(n=750)$ with $65.38 \pm 10.16 \mathrm{~mm}$ in shell length, were collected by scuba diving ( $n=30 \mathrm{mo}-1)$. A water temperature and salinity every month were measured, at the depth of sampling $(3 \mathrm{~m})$ using thermosalinometer.

\section{Biological Examination and Preparation of Histological Speci- men}

The M. galloprovincialis sampled were individually examined in the laboratory, immediately transported from the sites after samplings.
The size (shell length) of the mussels was measured with calipers, and the total wet weight (TW), wet meat weight (WMW) and shell weight (SW) were recorded by analytic balance to the nearest 0.001 $\mathrm{g}$ to calculate condition index $(\mathrm{Cl})$ according to the formula of Aguirre [20] and Rayyan \& Chintiroglou [21]:

$$
C I=\frac{W M W}{T W-S W} \times 100
$$

For every individual collected, the organs including gill, mantle, gonad and gonoducts, digestive gland tubules, stomach/intestine, and connective tissue were fixed in Davidson's fluid more than 24 hours after anatomical examination. The specimens were then dehydrated in a graded ethanol series before embedded in paraffin. Two parallel oblique-longitudinal sections (2- $\mu \mathrm{m}$ thick) were made mantle from a single specimen, and the individual sections were stained with hematoxylin and eosin for the observation. These histological sections were examined under optic microscope for gametogenic activity, presence of parasites and pathological alterations.

The reproductive status and mean gonadal index was assessed by microscopic observations of the slides. The gonadal index (GI) were calculated as the following formula of Seed [22]:

$$
G I=\left(\frac{\sum n i . S i}{N}\right)
$$

where ni : number of individuals at each stage of reproductive cycle, $\mathrm{Si}$ : score of the stage and $\mathrm{N}$ : total number of individuals.

\section{Pathological Examinations and Analyses}

To evaluate monthly pathological state including infection from parasites or diseases, we use the prevalence, it was calculated as:

$$
\% P v=100 \times \frac{n_{i}}{n_{m}}
$$

where $\% \mathrm{Pv}$ is monthly prevalence in percentage. $n_{i}$ indicates the number of infested host, $M$. galloprovincialis. $n_{m}$ is the number of mussels analysed in month $\mathrm{m}$. The nm equals to 30 in the analyses for the infection from excepting $S$. mytilovum, infecting only female mussels in each monthly sample. As a major and aquaculturally important biological responses, heamocytic infiltrations [23] were taken into account of the analyses. Presence or absence of the heamocytic infiltrations was also observed during the biological observation.

The obtained observations of parasites and indices were explanatory analyzed. Time series of the prevalence of dominant parasites were investigated, and the dynamics of the pathological state was visually evaluated through surveyed year. The other statistical tests were conducted upon the pathological states of hosts and parasitism along seasonal and reproductive cycles. Dependency of presence of parasites upon seasons and reproductive cycles were examined using Fisher's Exact Test. To specify the season with dependency found, pare-wise test was conducted. To evaluate ecological (i.e. environmental and biological) association between presence or absence of parasites and on-site enviromental conditions, salinity and temperature, and biological conditions as $\mathrm{Cl}$ and $\mathrm{Gl}$, generalized liner model was applied. Wald statistic were evaluated to determine significant environmental variables and biological conditions associated to presence or absence of the dominant parasites at $\alpha=0.05$ level. We examined the dependency of heamocytic infiltrations upon the dominant causal parasite in the observation using Fisher's Exact Test with multiple comparisons. R version 2.15.2 (R Core Team) was applied for all explanatory analyses and 
statistical tests in this study.

\section{Results}

\section{Pathological Observation}

We found different types of parasites on histologically examined sections. The prevalence and severity of infections were highly variable throughout the sampling period. Dominant parasites were two: Ciliophora-like ciliates (43\%) and S. mytilovum (32\%). They were always majority in all months of the survey years.

\section{Ciliophora-like Ciliate}

Ciliophora-like ciliate were generally the most dominant parasite through timeseries excepting February, March, August and October in 2010. Its prevalence varied between months; it was ranged from $6 \%$ to $90 \%$. For the 750 examined mussels, $43 \%$ were infected with Ciliophora-like ciliates [Fig-2]. The percentage of the infected mussels among males and females were $46.2 \%$ and $53.5 \%$, respectively. They were notably observed within the digestive epithelial cells of gut, stomach and digestive diverticula. Occasionally, they were found in the lumen of the digestive tubules. No haemocytic reaction was observed. These protozoans were round to pear shaped and measured 10-12 $\mu \mathrm{m}$ in length. The nucleus was often fragmented into more than five basophilic micronuclei which were sometimes condensed into one globular macronucleus [Fig-4](A).

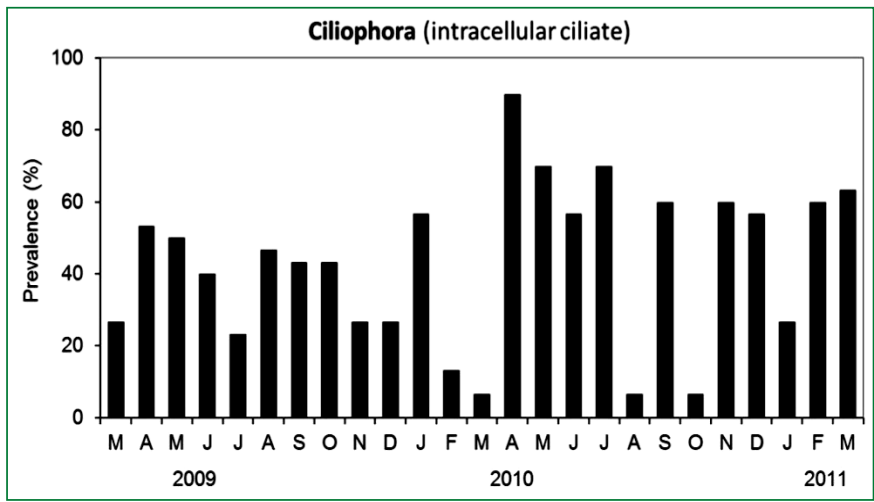

Fig. 2- Monthly variation of prevalence's the intracellular ciliate Ciliophora infected Mytilus galloprovincialis from M'diq between the periods of study. $\mathrm{N}=$ number of females/months.

\section{Steinhausia mytilovum}

The microsporidian parasite, Steinhausia mytilovum, was recorded throughout the sampling period excepting March 2011 [Fig-3].

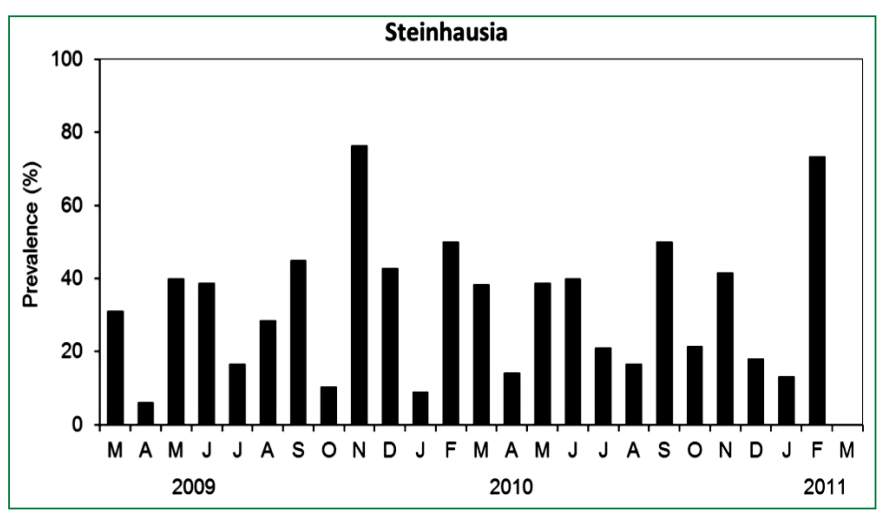

Fig. 3- Monthly variation of prevalence's Steinhausia infected Mytilus galloprovincialis from M'diq between the periods of study. $\mathrm{N}=$ number of females/months.
The oocytes of $32 \%$ female M. galloprovincialis analyzed ( $n=387$ ) were parasitized and the number of infected oocytes was lower than uninfected oocytes. It was primarily located in the cytoplasm of vitellogenic oocytes but in few cases, it was also observed inside the nucleus $(1.5 \%)$. Most of the infected oocytes showed a single sporocyste. A multiple infection (2-4 parasites per oocyte) occasionally occurred within a single oocyte. These sporocyts appeared spherically shaped, $(7.5-12.5 \mu \mathrm{m}$, mean $10 \mu \mathrm{m}, \mathrm{SD} \pm 1.88, \mathrm{n}=8)$ in diameter [Fig-4](B) and contained a widely varied number of spores (1-40). In some cases, a sporocyst was observed in necrotic 00cytes and the infection was accompanied by a haemocytic reactions of the affected gonadal follicles.

\section{Urastoma sp.}

Among the 750 mussels analyzed, $2.5 \%$ were parasitized by the turbellarian Urastoma cyprinae. It was observed among gill filaments only in winter 2009 and summer 2009 and 2010 at prevalence ranging from $3 \%$ to $23 \%$. Shape of this turbellarian varied between round and oval; had a mean length of $307.5 \mu \mathrm{m}$ (SD \pm $96.28, n=8$ ) and its number per histological section was 1-2 [Fig-4] (C). Haemocytic infiltrations of gill filaments surrounding Urastoma were noted.

\section{Rikettsia-like Prokaryotes}

Basophilic inclusions of Rikettsiales-like prokaryotes (RLPs) were observed in the epithelial cells of digestive diverticula and in gills cells. Their presence was noted in April, August and November 2009 as well as in June and November 2010 with low prevalence does not exceed the $7 \%$. The length of the intracellular colonies was $12.5 \mu \mathrm{m}$ in digestive cells of diverticula and ranged from 135 to $200 \mu \mathrm{m}$ in gills cells. Commonly, only one colony was observed individual tissue. The infected cells were hypertrophied, however, no clear heamocytic infiltration was found for the pathogenic conditions.

\section{Marteilia sp.}

Throughout the sampling period, two mussels were observed affected by the paramyxum Marteilia sp. in May 2010 and in March 2011. Different stages of the parasite spread over the digestive gland of infected hosts. Young plasmodia were mainly found in the stomach epithelium; while sporangia stages were detected in the epithelial cells of digestive diverticula and secondary ducts. Marteilia cells have a size ranging from $15 \mu \mathrm{m}$ up to $27.5 \mu \mathrm{m}[\mathrm{Fig}-4](\mathrm{D})$. No haemocytic infiltration response was associated to the observation of this pathogenic agent; though, epithelia of digestive diverticula appeared to be malformed with intensive infections.

\section{Pseudoklossia sp.}

Macrogamonts of a Pseudoklossia-like coccidian were observed inside of cells and also in the lumen of kidney tubules in $1.5 \%$ of examined mussels. Infection of Pseudoklossia-like coccidian was observed during the summer 2009 and in February, April, May and November 2011. The prevalence was ranged from 3 to $7 \%$. More than 9 parasites per individual tubule were observed. Although infected kidney cells were hypertrophied, any association of haemocytic response to Pseudoklossia spp. was observed in the specimens [Fig-4](E).

\section{Extracellular Ciliate}

Three unidentified extracellular ciliate were recorded either on the gill surface or in gill water tubes of $2.5 \%$ of analyzed mussels. The 
maximum values of prevalence and mean intensity were $14 \%$ (April 2010) and 1.5 ciliates per histological section, respectively. Any specific host response was associated with these ciliates.

\section{Nematopsis sp.}

A small percentage $(0.4 \%)$ were infected with the protozoan parasite, Nematopsis sp. Their prevalence was 3\% each in April and august 2009 and also in January 2010. The parasite was only detected in the gill filaments and at very low intensity without pathological damages.

\section{Haemocytic Infiltrations}

Histological analysis revealed a haemocytic infiltrations in the connective tissue and epithelia of the digestive gland [Fig-4](F). This condition were observed in 236 of the 750 individuals analyzed and could not be linked to any detectable pathogenic agent. The observation was highly variable through the survey years [Fig-5].

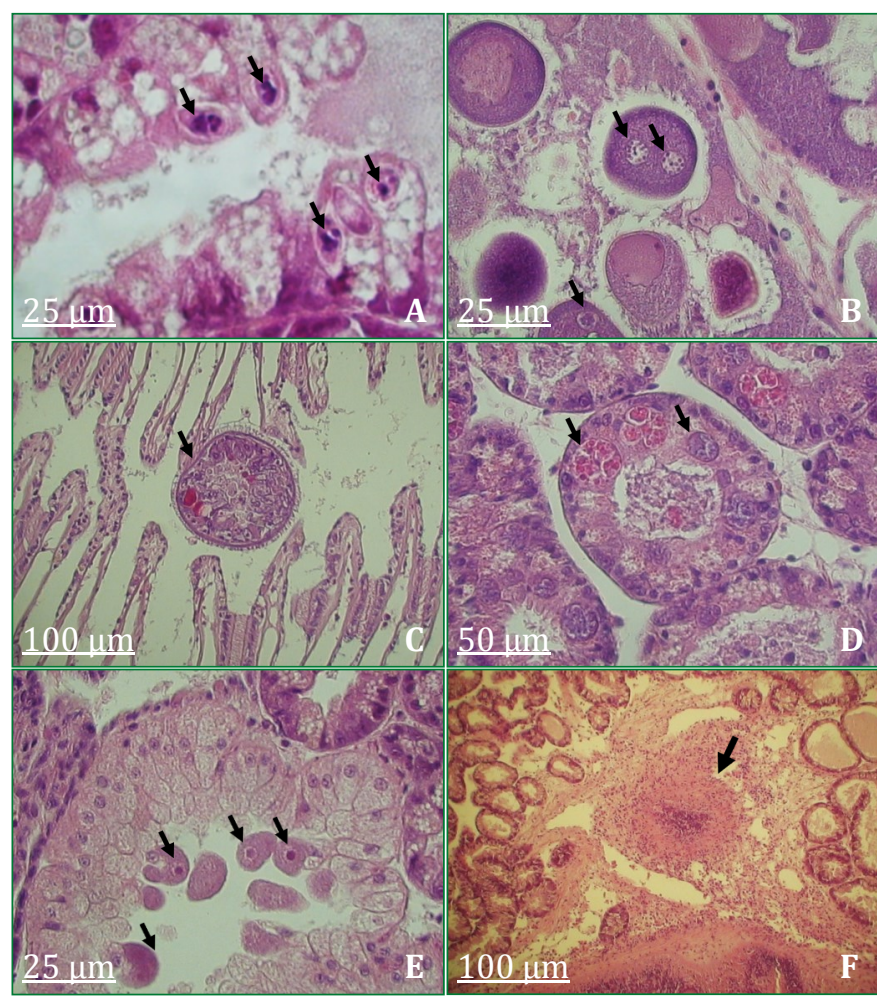

Fig. 4- Histological sections showing parasites and inflammation of Mytilus galloprovincialis ( $\mathrm{H} \& \mathrm{E}$ staining)

4A: infection of intracellular Ciliophora-like ciliate in the digestive gland; 4B: oocyte with two sporocystes multispored of Steinhausia; 4C: Urastoma cyprinae attached to gill lamellae; 4D: Marteiliosis, sporocysts identified wthin the epithelium of digestive diverticula; 4E: Pseudoklossia-like coccidian inside cells and also in the lumen of kidney tubules; 4F: haemocytic infiltrations in the connective tissue of digestive gland.

\section{Association of Parasites to Ecological Conditions and Impact as Haemocytic Infiltrations}

The presence and absence of Ciliophora-like ciliates was significantly dependent upon the seasons $(p<0.01)$. Infection in spring was significantly higher than winter based on the pairwise test $(p<$ 0.01). On the other hand, S. mytilovum infection was independent from the season $(p=0.07)$. The presence or absence of Ciliophoralike ciliates statistically associated to the variability of salinity $(p<$
0.05), [Table-1]. On the other hand, presence or absence of S. mytilovum was not statistically associated to neither the salinity $(p=$ $0.47)$ nor temperature $(p=0.78)$. GI was indicated as the significant variable in the GLM model $(p<0.05)$, [Table-1].

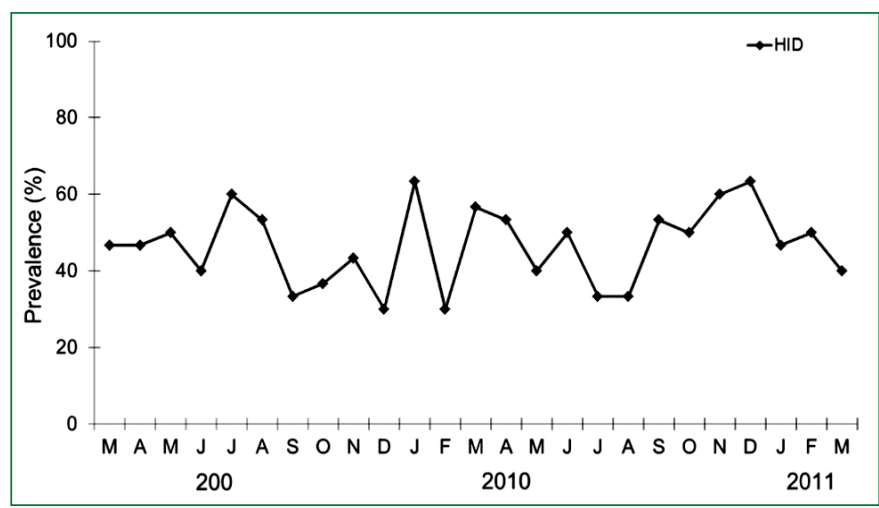

Fig. 5- Temporal of Change frequency of heamocytic infiltration in digestive gland (HID) at Mdiq samples between March on 2009 and March on 2011

Table 1- Mytilus galloprovincialis. Logistic regression results showing the relationship between the different study ecological parameters and the presence of Steinhausia mytilovum and Ciliophora like organisms, with respect to the total number of mussels, at Mdiq

\begin{tabular}{lcccc} 
Parameters & Coefficient & $\begin{array}{c}\text { Std. Error } \\
\text { Steinhausia mytilovum }\end{array}$ & Wald & $\operatorname{Pr}(>|z|)$ \\
\hline Intercept & -9.48 & 7.29 & -1.3 & 0.193 \\
Temperature & 0.02 & 0.071 & 0.282 & 0.777 \\
Salinity & 0.14 & 0.193 & 0.728 & 0.466 \\
Gonadic index & 1.389 & 0.654 & 2.123 & 0.033 \\
Condition index & 0.007 & 0.007 & 0.922 & 0.356 \\
\hline \multicolumn{5}{c}{ Ciliophora - like organisms } \\
Intercept & 15.634 & 5.025 & 3.111 & 0.001 \\
Temperature & 0.063 & 0.05 & 1.257 & 0.208 \\
Salinity & -0.509 & 0.135 & -3.754 & 0 \\
Gonadic index & 0.178 & 0.452 & 1.588 & 0.112 \\
Condition index & -0.001 & 0.005 & -0.218 & 0.827 \\
\hline
\end{tabular}

Dependency of haemocytic infiltration in digestive gland upon Ciliophora-like ciliates was not significant $(p=1)$. On the other hand, significant dependency of haemocytic infiltration in Oocytes upon presence of $S$. mytilovum was observed $(p<0.05)$, [Table-2].

Table 2- Mytilus galloprovincialis. Fisher Exact Test results showing the relationship between the massive haemocytic infiltration and the presence of majors parasites; relationship between the presence \& absence of haemocytic infiltration in gonad and the Steinhausia mytilovum and relationship between the presence \& absence of haemocytic infiltration in digestive glande and the Ciliophora-like organisms; with respect to the total number of mussels, at M'diq

\begin{tabular}{|llcccc|}
\multirow{2}{*}{ Parasite } & Relationship & \multicolumn{4}{c|}{ Haemocytic Infiltration } \\
& & Presence & Absence & Prevalence & Total \\
\multirow{2}{*}{ Steinhausia mytilovum } & Presence & 77 & 48 & $62 \%$ & 125 \\
& Absence & 31 & 232 & $12 \%$ & 263 \\
\hline \multirow{2}{*}{ Ciliophora-like } & Presence & 112 & 312 & $26 \%$ & 424 \\
& Absence & 86 & 239 & $26 \%$ & 325 \\
\hline
\end{tabular}




\section{Discussion}

This paper is the first histopathological study specifically in southern Alboran area, Morocco. Histopathological approach with systematic samplings with consideration in biological and environmental information in this study allowed us to investigate potential pathogens and their dynamics as the ecological responses to the both reproductive cycle of $M$. galloprovincialis and seasonal environment in the area. The conducted pathological examinations of the M. galloprovincialis and the findings, including identification of nuisance pathogens in the other waters, are the first reference in this area in spite of the importance of the area in the Moroccan aquaculture.

The infections have not caused observable mortality in the site, but we suggest continuous histological study with continuous ecological monitoring efforts along the found reproductive cycles and local environmental dynamics through the year.

Reproductive activity of $M$. galloprovincialis in the study area is continuous through entire seasons, and it does not have specific inactive phase of gonadal development as a local stock. Intensive spawning in this area occurs between spring and summer but the process of both emission and rapid redevelopment of gametes take place simultaneously through seasons. During studied period, the temperature and salinity of the site coastal waters were varied respectively between $15^{\circ} \mathrm{C}$ and $21^{\circ} \mathrm{C}$ and between 35 and 37 [24].

Ciliophora-like ciliates and $S$. mytilovum were present throughout the reproductive cycle of the $M$. galloproviencialis during the surveys. Ciliophora-like ciliates are intracellular parasites in the digestive gland, especially inside of diverticula $[7,25,26]$. After the first publication of observation in the North Sea [25], many authors have confirmed its presence in the Atlantic Ocean [27], in the Mediterranean Sea [28] and in Australian water [29]. Variability of the prevalence through seasons was suggested along the Atlantic coast of Spain [7]. However, association of the variability of the prevalence to the local conditions were not found in the Altantic coast of Spain. In our observation, the parasite was abundant in spring and decreased in winter, and the presence of Ciliophora-like ciliates associated to salinity variability. Change in water property, including salinity and oxygen, enhances the infection of Ciliophora-like ciliates in Northern Mediterranean Sea, by presumably influencing the host conditions [30]. The surrounding land including M'diq had high local precipitation especially in winter 2009 to spring 2010, so the freshwater input of following season might be increased. Also, in the southern Alboran area, the surface water property seasonally changes depending upon the inflow and outflow of Gibraltar strait [31]. The inflow with Atlantic water (Salinity $=36.2$ ) through the Gibraltar strait is generally strong in spring to summer and weak in fall to winter and influence over the surface of Mediterranean water (Salinity $=38.45$ ) of southern Alboran [32,33]. Locally input freshwater and intensified inflow of the Atlantic water in the site may lower the salinity in the littoral water in the southern Alboran and enhance the infection of Ciliophora-like ciliates to $M$. galloprovincialis.

In our study, S. mytilovum were observed in three appearances inside in the cytoplasm and in the nucleus of M. galloprovincialis: without spore, with single spore and multiple spores up to 40 . Steinhausia spp. only infects female hosts in the oocytes in various appearances of the up to four cysts $[11,14,15,27]$. Anderson, et al [32] found cysts of Steinhausia spp. with more than 40 spores. Our findings regarding the characteristics of $S$. mytilovum infection is consistent to the past works in the various waters. On the other hand, prevalence in our observation were more than $30 \%$ in comparison to less than $20 \%$ in these past studies upon variety of bivalves including M. galloprovincialis.

Cysts with no spores were probably remained follicles after disappearance of the parasite. They were rarely observed always with the cysts with spores. The permanent presence of the infection of S. mytilovum associated to the continuous activity of the reproduction. The proliferation of infection was observed in the months of sexual maturity, from February to September. The minimum infection was observed in the spawning period probably because of the emission of the oocytes by the host. The found association between variability in infection of $S$. mytilovum and the gonad of the host is also explained from the above reproductive cycle. Significant relationship between prevalence and temperature or salinity was not found in our analyses. However, the biological response of mussels to the environmental variables including salinity and temperature has been studied, and variability in the reproductive processes in response to them has been suggested [33]. Salinity and temperature ambient water in the site would indirectly influence to the infections of $S$. mytilovum by determining the timing and intensity of reproduction.

Bignell, et al [15] highlighted to the dependency of heamocytic infiltration upon parasitism of $S$. mytilovum to $M$. edulis and $M$. galloprovincialis in the North Atlantic. In our analysis, the dependency of heamocytic infiltration in acini upon the presence of $S$. mytilovum in M. galloprovincialis in southern Alboran area was confirmed. As one of the consequences discussed, for example in [15], intensive development of heamocytic infiltration limits the healthy growth of the other organs. In our study, we found that the heamocytic infiltration with S. mytilovum occationally reached nearly $50 \%$ of female. Considering the potential risk upon the local aquaculture, continuous monitoring of the infection and impact of the $S$. mytilovum is preferred. On the other hand, dependency of hemocytic infiltration to the digestive glands to Ciliophora-like ciliates were not found in this study. However, the potential risks of the heamocytic infiltration by these ciliates need to be considered based on the past findings in the bivalves. For example, Spiers, et al [28] found the association between the observed infiltration in oysters producing region of Western Australia. Also, the cause of the heamocytic infiltration in the digestive grand should be investigated considering in the high ratio in this area through the survey years.

The duration of the sampling allowed us to detect other parasites including Marteilia sp., U. cyprinae, Rikettsia infections and A. mytili. They were minority and not observed with detectable impact on the host, such as heamocytic infiltration. Yet, all are the potential pathogens upon socio-economically important bivalves in the other regions. For example, intensive infection of Marteilia sp. was found in two of 750 individual hosts with very low condition index in our study. Marteilia sp. causes emaciation and mortalities of Oysters [34] and of mussels $[7,27,35,36]$. Heavy infection of Urastoma cyprinae (Platyhelminthes) would result in the disruption of gill filaments [7]. R. infections can cause hemocytic response upon infected tissue through hypertrophy of cells [37].

We investigated in influence and its significance of the reproductive cycles and environmental variability on the pathology of M. galloprovincialis with available timeseries of the survey results. Although the area has not experienced mortal outbreaks of the infections of found parasites, further investigations and efforts of prevention are necessary for the sustainable aquaculture and natural stock in the southern Alboran area. Numbers of samplings in appropriate timing 
in the target ecosystem and quality of the histopathlogical analyses in laboratory assist researchers to obtain quantitatively and qualitatively sufficient information in the pathological investigations. Taking regional oceanographic dynamics into account, such as alterations of circulation, variability of thermohaline events and sea level rise, continuous histopathological monitoring through seasons and years may be necessary in the southern Alboran. Impacts on reproduction and recruitment in bivalves can be investigated in relation with climate change $[38,39]$ based on the continuous monitoring efforts. Further investigations in the pathological mechanism with larger scale (i.e. synoptic and global scale) environmental drivers may provide practical information for the sustainability of the both aquacultural and natural stock of $M$. galloprovincialis in the southern Alboran area. Moreover, considering the limitation of the histology and the difficulty of observation of the detected parasites, such as Martelia, integrative design of the monitoring with molecular analyses may be effective. Comprehensive monitoring of the histopathological approach with ecological and molecular biological investigation should be conducted for future.

Conflicts of Interest: None declared.

\section{References}

[1] Lubet P. (1973) Expose synoptique des donnees biologiques sur la moule Mytilus galloprovincialis, Fisheries Synopsis, FAO, 88.

[2] Koehn R.K. (1991) Aquaculture, 94, 125-146.

[3] Comesana A.S., Posada D., Sanjuan A. (1998) J. Exp. Mar. Biol. Ecol., 223, 271-283.

[4] Cherfaoui N. and Doghmi H. (2002) Sciences de l'ingénieur, 259-265.

[5] El Moumni B. (1995) Contribution à l'étude des paléoenvironnements sédimentaires au Quaternaire terminal en Mer d'Alboran. Cas de la marge méridionale, Thèse de Doctorat d'État, Université de Meknès, 259.

[6] Lecointre G. (1963) Recherches sur le Néogène et le Quaternaire marin de la côte atlantique du Maroc, Mém. Serv, géol. Maroc, Rabat, No. 174.

[7] Robledo J.A.F.,. Santarém M.M and Figueras A. (1994) Aquaculture, 2, 619-620.

[8] Chintiroglou C.C., Arsenoudi P. and Scouras Z. (2002) Ninth International Congress on the Zoogeography and Ecology of Greece and Adjacent Regions, Hellenic Zoological Society, Thessaloniki, 10.

[9] Sindermann C.J. (1970) Principal Diseases of Marine Fish and Shellfish, Academic Press, New York, 369.

[10]Figueras A.J. and Villalba A. (1988) Monografías Acuicultura. CAICYT.

[11]Bower S.M. and Figueras A.J. (1989) World Aquaculture, 20(4), 89-93.

[12]Peharda M., Richardson C.A., Mladineo I., Šestanović S., Popović Z., Bolotin J. and Vrgoč N. (2007) Mar. Biol., 151(2), 629638.

[13]Villalba A., Mourelle S.G., Carballal M.J. \& Lopez M.C. (1993) Dis. Aquat. Org., 17, 205-213.

[14]Villalba A., Mourelle S.G., Carballal M.J. and López C. (1997) Diseases of Aquatic Organisms, 31, 127-139.
[15]Bignell J.P., Stentiford G.D., Taylor N.G.H., Lyons B.P. (2011) Marine Environmental Research, 72, 25-32.

[16]Menioui M. (1990) Bull. Inst. Scie., Rabat, 45-49.

[17]Idrissi J.L., Orbi A., Zidane F., Hilmi K. and Sarf F. (2001) Bulletin de l'institut scientifique, Rabat, 23, 65-70.

[18]Furnestin J. (1960) Revue des Travaux de I'Institut des Pêches Maritimes, 24(1), 5-119.

[19]Crépon M., Richez C. and Chartier M. (1984) J. Phys. Oceanogr., 14, 1365-1382.

[20]Aguirre M.P. (1979) Bol. Inst. Esp. Oceanog., 5, 109-159.

[21]Rayyan A. and Chintiroglou C.C. (2003) Diseases of Aquatic Organisms, 57, 271-273.

[22]Seed R. (1975) Pubbl. Stn. Zool., Napoli, 39(1), 317-334.

[23]Parry H.E. and Pipe R.K. (2004) Aquatic Toxicology, 69, 311325.

[24]Bhaby S., Belhsen O.K., Errhif A. (2013) Journal of Fisheries and Aquaculture, 4(2), 110-114.

[25]Bower S.M. (1992) The Mussel Mytilus: Ecology, Physiology, Genetics and Culture, Elsevier Press, Amsterdam, 543-563.

[26]Villalba A., Mourelle S.G., Carballal M.J. and López C. (1997) Diseases of Aquatic Organisms, 31, 127-139.

[27]Figueras A.J., Jardon C.F. and Caldas J.R. (1991) Journal of Shellfish Research, 10, 89-94.

[28]Spiers Z.B., Bearham D., Jones J.B., O'Hara A.J. and Raidal S.R. (2008) Journal of Invertebrate Pathology, 99(3), 247-253.

[29]Žiziek S., Gombač M. and Pogačnik M. (2012) Slov. Vet. Res., 49(3), 149-154.

[30]Criado-Aldeanueva F., Soto-Navarro F.J., García-Lafuente J. (2012) International Journal of Climatology, 32(2), 286-302.

[31]Bormans M., Garrett C., Thompson K.R. (1986) Oceanol. Acta., 9, 403-414.

[32]Anderson T.J., Hine P.M. and Lester R.J.G. (1995) Dis. Aquat. Org., 22, 143-146.

[33]Lemaire N., Pellerin J., Fournie M., Girault L., Tamigneaux E., Cartier S. and Pelletier E. (2006) Aquaculture, 261, 729-751.

[34]OIE (2000) Diagnostic manual for aquatic animal diseases, 3rd ed., Paris: Office International des Épizooties, 151-154.

[35]Comps M., Park M.S. and Desportes I. (1986) Protistologica, 25, 279-285.

[36]Auffret M. and Poder M. (1983) Rev. Trav. Inst. Pêches Mar., 47, 105-109.

[37]Belvin S., Thomas B. and Mc Gladdery S. (2007) Les publication de la Direction de L'innovation et des technologies. Rapport de recherche-développement $n^{\circ} 159,24$.

[38]Petes L.E., Menge B.A. and Harris A.L. (2008) Ecological Monographs, 78, 387-402.

[39]Philippart C.J.M., Van Aken H.M., Beukema J.J., Bos O.G., Cadèe G.C., Dekker R. (2003) Limnol. Oceanogr., 48(6), 21712185. 